\title{
PIONEERS OF THE NORWAY COMMUNITY
}

\section{By B. L. WICK*}

While not in the same class with Henry Tuttle, Adam Schulte and others, I still can recall the happenings in the Norway community, and something of the struggles of the pioneers for more than half a century. I personally knew and talked with many of these sturdy men and devoted women, who were among the first settlers, many times. Often I have been told how they! braved the winter storms, how they fought the prairie fires and forded the swollen streams to save their stock from drowning after a fierce cyclone.

We have been told that Bill Gue was the first white man who lived in the grove north of town which still bears his name, how he preferred to reside among the Indians, and when white settlers arrived in large groups, he alleged it was too crowded and removed to the west. One son, Louis, preferred to mingle with his white neighbors, later enlisted in the army and was killed during the Civil war.

We do not know much about the Indian wars in this part of the state, before the coming of the white man, until Johnny Green, originally a Pottawattamie, with a remnant of a band of Mesquakies of the Sac and Fox tribe, drifted back from Kansas in the fifties and often camped in the grove north of town, also along Prairie Creek, as well as in Scotch Grove for several weeks during the winter season, where they obtained food by hunting and if the game was not plentiful, the squaws would go around begging for meat and flour from the white neighbors. They were friendly and never caused any trouble, as far as I have been informed.

\footnotetext{
*Address delivered by B. I. Wick, historian and attorney, of Cedar Rapids, Iowa, a former resident of Norway, Benton county, Iowa, on occasion of the lowa, a form annual meeting of the old Settlers' meeting at Norway, in Benton seventeenth annual meeting of the Old Sed at Cedar Rapids, October 8, 1947, his obituary appearing on p. 246, Vol XXIX, No. 3, ANNALS of IowA. He had been a frequent contributor to this publication. 
Indian Hill west of the grove north of town was a favorite camping place of the red men during the summer. They would arrive frequently late at night with their ponies and baggage and in the morning have a dozen tents or wickiups, where they would remain for several weeks at a time. They seemed to love these old camping places, near where they had buried their dead and would recall among the white settlers, the good old days, when game was plentiful and fish could be caught in every stream.

Long before Norway was even thought of, a postoffice was opened, called Fremont, on the Toledo road some ten miles northeast of here, kept by an old pioneer by the name of Livermore. Another postoffice was established on the county line some two miles north of what later became Walford and conducted by Wes Alsbaugh. The settlers on the south side got their mail as a rule in the Colonies, a Communistic corporation locating in Iowa county in 1855, where some fourteen hundred persons in a short time erected seven small villages, where they lived for more than three-quarters of a century, contented and happy "bearing one another's burdens", in accordance with the basic principles of their creed.

I cannot tell you of all the early settlers of whom many stories have been related, but only a few of the most outstanding and best known citizens, such as John Tanner born in New York state in 1812, who settled in this county not far from here in 1856 and who early became interested in fruit culture and planted a large apple orchard in the early days. In the fall of the year he would drive around the community in a lumber wagon filled with apples, and many a boy was glad to see the old man drive in to a farm home, for he realized there would be plenty of apples to eat for weeks to come. Cicero Tanner, the son of John Tanner, also became interested in the development of apple orchards and set out at least 
two orchards, the last one in Linn county a few miles east of Atkins, where he lived for many years. He attended the horticultural meetings and developed an' apple of the hardy variety, still known as the Tanner apple.

However, the most outstanding person was J. L. Budd, who settled in Parker's Grove in the sixties and conducted a nursery for some years. He encouraged everyone to plant apple trees and even went to Russia and brought back many varieties of apples such as the Siberian crab. He was appointed a professor at Ames where he died in 1904 , seventy years of age. We had men of the type of Sam McGrenahan of Scotch-Irish descent on whose land Newhall was laid out, a strong-minded Presbyterian, who started the first church with a few members, where they convened at stated times in his barn. His sayings and statements have come down to us in trite sayings on politics as well as on religion.

A notable character here was an outstanding Scotchman by the name of William Pirie, a blacksmith, who invented the iron sectional harrow which became in general use later, all over the country.

Another unique character in this town, was known as Fred Folz, mechanical genius, who labored for a number of years to devise a method of coupling freight cars, who got a brakeman to help him with his invention. The shrewd railway man saw the value of such an invention and later secured a patent in his own name and became wealthy, while poor Folz died in poverty dreaming of wealth which had passed his door.

Another character known for his industry, was Ole G. Berg, a Norwegian, who became the best wagon maker in this part of the state having been duly trained in wood working before coming to America. His wagon was known for substantial strength and durability, always made of seasoned material. The old man had two sons who helped him in his work. One son, Hans, was his favorite, a likeable young man, who excelled his father in 
workmanship, but whenever some of his chums came around he would leave the shop to go hunting and fishing, especially during the prairie chicken season, and would be gone for several days. A kindly neighbor one day tried to persuade the old man to keep his son at work and relieve him of some of his responsibility, but the old man replied, "Hans is not lazy as you call it in dis country, but he joost don't like to work."

The old rhyme frequently quoted during these early days in Iowa would apply to this lover of hunting:
When the long hot summer's fadin'
And the nights are cool and still
When the goldenrods and the asters bloom
On every prairie hill.
When the air is new with hoar frost
And the year is in its prime
Then is when life gets best worth livin'
When it's' prairie chicken time.

\section{Communistic Colony ABandoned}

In the early days, even before the Amana society was organized, another Communistic society was formed composed of Germans who had come from St. Louis in 1851 and adopted a Communistic plan akin to that of the Amana society. One of these members was Henry Groth, a well known blacksmith and a hard worker, who devoted all his time to the labor assigned him, while some of the other members of the community, it was said, talked and smoked and accumulated nothing. Groth was close-fisted and felt that all should do their share of the work if they expected to share equally in the profits of the enterprise. He early saw, that such a Communistic system would not work, and with some others the plan was abandoned and the land was parceled out among the members individually.

Such has always been the end of Communistic societies. There must always be a unity of purpose, and if all shall share in the venture, they must all devote their time and energy in the upbuilding of the assets of the organization. 
The well known English rhymer, more than a hundred years ago in arguing against Communism, has the following: "Who is a Communist? One who has yearnings, for equal division of unequal earnings, idler or. bungler, or both, he is willing to fork out his penny and pocket your shilling."

Henry Groth became a successful farmer and accumulated a fortune for those days and as they had no children, his wife was anxious that some provisions be made for her during her lifetime. Her husband, in order to save money, drew his own will in German, fully believing that all law was the same in all countries. When the aforesaid will came up for hearing, the court found, that instead of inheriting all the estate by the wording of the instrument duly translated, the widow only obtained the income from the estate during her lifetime. It is not necessary to add, that the widow became much wrought up by such decision of the court, which she claimed was wrong; but there was nothing to do, except to appeal, and that was costly.

In order to spend as much money as possible, she obtained an order for a monument to be erected over her departed spouse, costing some eighteen hundred dollars, to be paid out of the assets of which she had only a life interest. The legatees, who were interested in this estate made the spouse much trouble in demanding reports how this money was invested. One day one of these lawyers, representing the legatees came to me, and asked how long the old lady was likely to live. I replied, that I did not know, but that the widow fully believed in the German proverb, that whenever someone desired a person dead in order that they might get an estate, such person would always live, seven years beyond his allotted time. The lawyer replied, "If that is the case, I will not be able to get any fees out of this estate in my lifetime. You better approach her about a settlement now." We later made a full settlement by paying off the legatees, and Mrs. Groth lived not only the seven years, but much longer. 


\section{MARKeTING REQUIRED LoNg TRIPS}

Before the arrival of the railroad the settlers had to take their grain and dressed hogs to market at Muscatine or Dubuque, and such a trip would require three or four days. Such person would bring back a little money, some sugar and coffee, a calico dress for the wife and a rattle for the baby. These pioneer times were strenuous years for these settlers, but they enjoyed life. They were young. They enjoyed to work and were happy and content amid their new surroundings. They turned the prairie sod by use of oxen, built their log houses and their strawthatched stables, made their own furniture, built their own rail fences as well as made their own clothing. They were all self-reliant and could do all kinds of work in their own fashion and got along.

With the coming of the Ure family to Scotch Grove in the early forties, a great many of the Scotch people followed most of them coming direct either from Canada or Scotland, such as the Mitchells, McGregors, McFarlanes, Russels, Primroses, McLarens, Morrisons, Brownlees, Andersons, Cleghorns, Parks, McKinnons, Johnsons, McNees and many others. A church was erected in 1858 , Margaret Ure donating ten acres of land for the site, at the south edge of Scotch Grove, which organization was maintained for more than half a century.

The early Scotch settlers brought with them from across the seas their religion, their customs, as well as many of their belongings such as the crusie, which was used in nearly every home, a sort of a lamp with a wick deposited in an iron receptacle filled with oil. Later, tallow candles came into use. The coffee mill was frequently attached to a tree, adjoining the log house in the edge of the forest, which was often observed in the early pioneer days. Burns' birthday was observed every year and in passing a traveler could hear the sound of the bagpipe and hear the Scotch songs sung, while the teakettle was on the stove, the smell of tea reminded everyone present of bonny Scotland. 
The first Norwegians who settled in the county, came from La Salle county, Illinois in the early fifties, such as Jonas Norland, Osmond Tuttle, Mrs. Darnell, Elling Ellingson, the Tow and the Strand families and many others. Later, others followed, some came from Clinton county, others coming direct from Norway, such as Bergesons, Petersons, Johnsons, Christensens, Dyrlands, Hollands, Hougens, Hages, Olsons, Guddals, Tweeds, Sundes, Muslands, Lunds, Egnes, Steffensons and many others. They early invested their money in prairie land, erected $\log$ houses, straw sheds, built their own Lutheran church and formed their own family circles, believing that in union there was strength. Many of them were homesick, lonesome and unable to speak the language, and in order to help many of these homesick persons, they generally met around the festal boards, during Easter and Christmas time, furnished food such as lute fish, sardines and herring as well as various kinds of cheese all brought from the old country. They would sing the old folksongs, so familiar to all. These were the happy days among these immigrants, who passed their lives among total strangers out here on the open prairies, exposed to the fierce storms with which they had not been familiar before arriving in America.

Osmond Tuttle, one of the first settlers, donated seven acres of land for a depot site, on the coming of the railroad through the county. He was far-sighted and early saw that a location of a depot adjoining his land, would be a financial advantage not only to himself, but for all his countrymen living in the vicinity. C. G. Turner, some years later, when Watkins was laid out, gave a like amount of land for the same project, owning considerable land in the vicinity.

The Germans began to settle in this county in the late fifties and the early sixties and invested their money in lands, which later grew in value. Among some of the best known of this group locating on the north side of 
Prairie Creek were Beckers, Schultes, Pickerts, Freses, Davis, Boddickers, Behls, Decoltzs, Kimms, Stallmans, Busmans, Millers, Voss, Englands, Nells and many others.

It is recorded that Father William Emmons of Iowa City, was the first Catholic priest to conduct mass in this town. His parish extended over Johnson, Iowa, Linn, Benton and Tama counties. He really started the scattered missions, where elaborate churches were later erected. $\mathrm{He}$ was a strong-minded, aggressive and fearless priest who in early days exercised a great influence among the German immigrants, who had come across the seas to make their home in a strange land. I often saw him and heard him preach at Iowa City, during my student days.

\section{VARIED NATIONALITIES HaRmonious}

This often has been called a strange community, where so many different nationalities came to live side by side. These immigrants found on arrival a hearty welcome from the native-born and they were protected in their legal rights, with as much consideration as if they had been born in this country. They gradually acquired the English language, sent their children to the country schools, became useful citizens and learned from others the art of farming in America and the use of modern machinery, many of whom had not known before the use of machinery, having only been familiar with the scythe, the sickle, the spade and the hoe:

There grew up among these people a friendliness and a helpfulness, such as was not known in many other communities. Whatever race the immigrants sprang from or whatever religion they professed, they were welcome and became real neighbors, without strife. No stranger was denied a night's lodging. Although the houses were small, there was always a place in one corner of the house for a night's lodging and a free breakfast on departing, the next morning. It has often been told how a stranger on the Toledo road on a rainy, fall 
night saw a light burning, approached to the house and knocked at the door, asking for a place to stay overnight. The man of the house got up, asked the stranger where he came from and where he was going. That was all. He went outside the house, called the hired man to get up, harness the team and get into the cornfield, that it was time to be out. The hired man did so and after he had gotten down towards the stables, the man of the house said to the stranger, "Crawl up the ladder and jump into the bed left by the hired man. I fear that Jack will think that it is a long time until morning." I cannot vouch for the truth of this story, which has been often told. This, however, is true that this cordial feeling and helpfulness, by the settlers of the locality, to strangers has been shown even down to recent times.

In every community, there must be leadership shown in order to succeed. Jake Springer, whom I knew well, coming here in 1852, and the first white settler in St. Clair township, was an outstanding personage, as well as James McQuinn who arrived four years later. Then there were others such as Bowers, Messengers, Knoufs, Buchanans, Terrys, Murrays, Schloemans, Harringtons, Sabins, Stockers, Jerry Lynch, W. S. Snow, Turner, Mayhews and many others.

These men were far-sighted and aggressive and frequently appeared in a body at the county seat demanding more bridges, better roads, more schoolhouses and even threatened at one time, it is alleged, to form a county by itself composed of southern Benton county, northern Iowa county and part of Tama county, in case that their just demands were not treated with due consideration.

The Vinton Eagle, was founded in 1855, and read for many years by nearly every household in the county. Bernard Murphy, better known as Pat Murphy, drifted into this county as a young man and became a member of the Jake Springer family until he entered the newspaper game at Vinton and in time became the owner of 
the Eagle. Consequently, Pat Murphy for many years was a friend of the people of the South Slope, and advocated fair treatment for these farmers who were entitled to better roads, to more bridges and that these settlers from the southern part of the county, should be duly represented in county offices. Norway, for many years, was a flourishing town drawing business south towards the Colonies, east to Scotch Grove and beyond and north some fifteen miles, until the Milwaukee road in the early eighties laid out Atkins and Newhall, which absorbed much of its trade.

\section{Business INDUSTRIES FlOURISHED}

Norway had in these early days two lumber yards, three backsmith shops, two wagon shops, five stores, grain offices, a flour mill, a bank, a newspaper, four churches and at one time four saloons, that seemed to do a thriving business so that no one went home thirsty, although many were unable to carry their drinks standing on their feet.

There arose early a friendly rivalry among the young folks living south of Prairie creek and those living north of Prairie creek, a historic stream which in flood time separated them for days at a time.

Ralph Terry, Tom and Will Buchanan, Clint Manville, Charles Messenger, John Bowers, the Schloeman boys, the Delana brothers, the Harrington boys and many others, all living on the south side, early bought shining top buggies, the latest silver-mounted harness decorated with ivory rings and would drive these roadsters, on rainy days back and forth, through the only street of Norway, to show off, to the envy of the boys on the north side, coming into town in lumber wagons, some on horseback and even others on foot. This friendly rivalry also existed among those who attended the high school in Norway, as the young folks on the north side felt that those 
on the south side, were stuck up and overbearing. However, as years passed, these friendly rivalries were forgotten and during the baseball and football seasons, they all fought in harmony with good feeling clubs from other towns.

The public school system, as early introduced into the state, was another means by which the young folks became united, the teachers coming mostly from Illinois, Ohio and eastern states, were instrumental in building up a community spirit, among this mixed population. The schoolhouse became a sort of center of the district, while during the week days the school room was used for teaching the young folks. Friday and Saturday night were given up to spelling schools, debates and some times for a lecture by some visiting stranger. On Sundays, church services were held, also singing schools were conducted and often the men met, for consultation in matters, in which they were all vitally interested. Today, that has all disappeared and I am informed, there is now only one independent school district functioning in Scotch Grove where, for so many years, they had some of the most outstanding teachers who were graduates of foreign colleges.

The school districts were confined to township organizations and many were the discussions held during these annual meetings as to expenses in building schoolhouses, as to salaries to be paid teachers, and many other problems which came up for general discussion.

As a young lad, I recall one of such meetings, when at a great expense a rabble-rousing person was chosen to speak in favor of enlarging the schoolhouse in Norway. The county school directors opposed this plan, but no one seemed able to talk against the arguments which had been made. John Declotz, a retired farmer, finally rose and in his broken English said, that he had heard the talk made in favor of schools, which was all right and he believed in learning. However, he felt that those who 
wanted so much schooling should pay for it themselves and he didn't see any reason, that a township should be assessed for making these improvements. Furthermore, he added that such an outlay, would not affect the speaker financially, as he paid no taxes. The proposition was overwhelmingly beaten.

\section{Agriculture Assisted IN TRANSFORMation}

These early settlers saw this great state of ours change, from an Indian frontier, to a vast farming state supplying food for millions of people in this country, as well as abroad. All this has come about, during the lifetime of some of these old settlers, some of whom are with us today and who have met with us, from time to time, and in which work for the upbuilding of the state, they have taken a leading part.

During these years these muddy roads have been paved or graveled. Automobiles are now standing in most dooryardsi and planes daily fly over our heads and we can within an hour's time get a plane that will take us to the east or the west coast within a few hours time. The radio is now found in most homes, announcing the happenings of the world. The self-binder, the trucks, tractors have taken the place of the scythe and the farm wagon. All these inventions, by the way, intended for the benefit and comfort and happiness of mankind, are now used in a bitter warfare for the sole purpose to destroy our much heralded civilization.

These old pioneers were a hardy lot of strong men and devoted women, who left for their families, large fortunes, which they had accumulated by hard work and saving, and they left besides, honored names of whom we should be all justly proud.

I cannot close this rambling talk, without quoting from my old friend, J. P. Gallagher of the adjoining county of Iowa, himself an old pioneer, of Celtic stock, when he writes: 
All gone, the brave old pioneers, Their like, we'll see no more, And only through the mist of years The trials they bravely bore.

When severing homes and kindred ties, And friends they deemed the best

They turned their steps toward the skies That fringed the boundless West.

\section{THE REAL NEED OF AMERICA}

It was Calvin Coolidge who discerned that what America and the whole world needs at this critical time is a greater application of Christian principles to everyday living. On one occasion he said:

"We do not need more material development; we need more spiritual development. We do not need more intellectual power; we need more moral power. We do not need more knowledge; we need more character. We do not need more government; we need more culture. We do not need more law; we need more religion.

"We do not need more of the things that are seen; we need more of the things that are unseen. All of our learning and science, our culture and our arts will be of little avail, unless they are supported by high character. Unless there be honor and truth and justice, unless our material resources are supported by moral and spiritual resources, there is no foundation for progress.

"A training of intelligence can do much, but there is no substitute for morality, character and religious convictions. Unless these abide, American citizenship will be found unequal to its task." 
Copyright of Annals of Iowa is the property of State of Iowa, by \& through the State Historical Society of Iowa and its content may not be copied or emailed to multiple sites or posted to a listserv without the copyright holder's express written permission. However, users may print, download, or email articles for individual use. 